\title{
A Renewable Energy Community: Key Elements
}

Technical Report NREL/TP-540-42774 January 2008

A reinvented community to meet untapped customer needs for shelter and transportation with minimal environmental impacts, stable energy costs, and a sense of belonging

N. Carlisle, J. Elling, and T. Penney

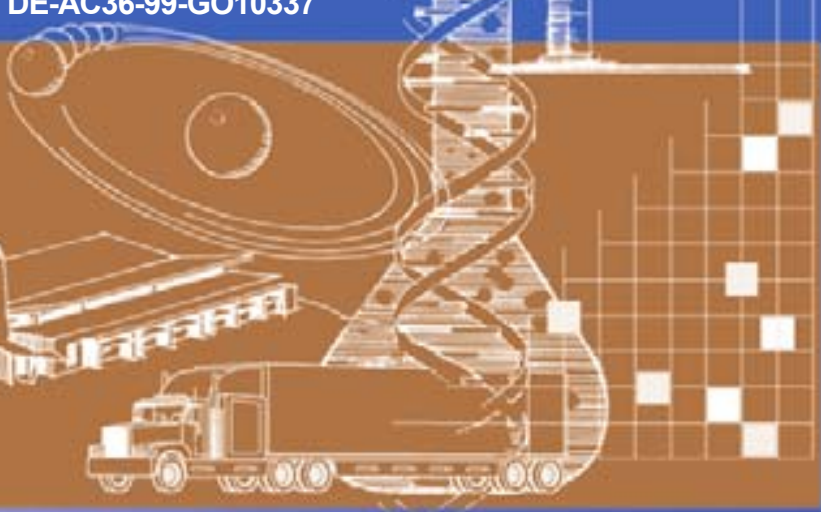




\section{A Renewable Energy \\ Community: Key Elements}

Technical Report NREL/TP-540-42774 January 2008

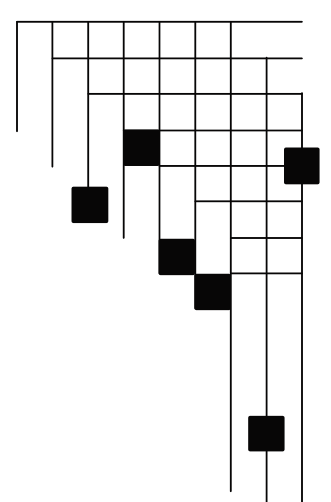

Prepared under Task No. 2940.0007

National Renewable Energy Laboratory

1617 Cole Boulevard, Golden, Colorado 80401-3393

303-275-3000 • www.nrel.gov

Operated for the U.S. Department of Energy

Office of Energy Efficiency and Renewable Energy

by Midwest Research Institute $\bullet$ Battelle

Contract No. DE-AC36-99-G010337 


\section{NOTICE}

This report was prepared as an account of work sponsored by an agency of the United States government. Neither the United States government nor any agency thereof, nor any of their employees, makes any warranty, express or implied, or assumes any legal liability or responsibility for the accuracy, completeness, or usefulness of any information, apparatus, product, or process disclosed, or represents that its use would not infringe privately owned rights. Reference herein to any specific commercial product, process, or service by trade name, trademark, manufacturer, or otherwise does not necessarily constitute or imply its endorsement, recommendation, or favoring by the United States government or any agency thereof. The views and opinions of authors expressed herein do not necessarily state or reflect those of the United States government or any agency thereof.

Available electronically at http://www.osti.gov/bridge

Available for a processing fee to U.S. Department of Energy and its contractors, in paper, from:

U.S. Department of Energy

Office of Scientific and Technical Information

P.O. Box 62

Oak Ridge, TN 37831-0062

phone: 865.576 .8401

fax: 865.576 .5728

email: mailto:reports@adonis.osti.gov

Available for sale to the public, in paper, from:

U.S. Department of Commerce

National Technical Information Service

5285 Port Royal Road

Springfield, VA 22161

phone: 800.553.6847

fax: 703.605.6900

email: orders@ntis.fedworld.gov

online ordering: http://www.ntis.gov/ordering.htm 
"We live in an extraordinarily challenging time - a time when we have learned to walk on the moon, but not yet how to walk on the earth"

William S. Becker ${ }^{1}$

1 Presentation to the 2nd Annual Intelligent Green \& Energy Efficient Buildings Conference \&Expo, March 29, 2006, Beijing, China. 


\section{Acknowledgements}

We appreciate NREL leaders Bobi Garrett and Doug Arent for their support of this initiative.

Thanks also goes to the many NREL staff members who provided valuable input and review including John Barnett, Howard Brown, Craig Christenson, Paul Denholm, Peter Lilienthal, Tony Markel, Chandra Shah, Walter Short, Roger Taylor, and Otto VanGeet.

In addition, many stakeholders outside of NREL have spent time with the authors providing significant information about their experiences with energy issues and cost tradeoffs, use of and interest in renewable energy technologies, and the overall feasibility of a renewable energy community. Thanks goes to Simon Walker, Actus Lend Lease; Piper Rhodes, Kennecott Lands; Jim Heid, UrbanGreen; Gary Lawrence, ARUP Urban Strategies; Nina Powers, Jodi John, and Shannon Staub, Sarasota County; Michael Ohlsen, Florida Energy Office; Roger Duncan, Austin Energy; and Larry Oswald, Global Electric Motorcars. 


\section{Executive Summary}

Increasing dependence on fossil fuel, primarily for buildings and transportation, threatens the world's long-term energy security and environmental sustainability. In fact, the buildings and transportation sectors use approximately $70 \%$ of the United States' energy use. Changing the way we design new communities using a renewable energy systems approach - with sustainable planning, net zero-energy homes, advanced vehicles, and innovative utility interconnectionscould significantly decrease this energy use, as well as its associated emissions and climate change impacts, both in the U.S. and worldwide.

The National Renewable Energy Laboratory (NREL) is assessing the feasibility of developing such Renewable Energy Communities to help Americans overcome our high level of fossil fuel use and ever-increasing dependence on foreign oil. Assessment efforts include:

- Working with several "green" ${ }^{2}$ developers who are grappling with energy issues and cost tradeoffs

- Surveying builders, developers, and stakeholders about their use of and interest in renewable energy technologies

- Conducting a literature review on the concept of Renewable Energy Communities ${ }^{3}$

- Gathering cross-discipline information from all NREL renewable energy/efficiency areas.

Findings reveal that there is little information available on how to integrate renewable technologies as a system in community building design. There is a real information gap and need to share renewable technology information with builders, developers, and stakeholders who are interested in pursuing renewable technology integration in communities. One purpose of this report is to help bridge this information gap; another is to describe and emphasize the "systems approach" to designing a Renewable Energy Community that provides the paradigm-shifting ability to develop these communities cost-effectively. Looking at the community system as a whole-linking homes with vehicles and addressing energy issues on a community level rather than individual households - makes good business sense. ${ }^{4}$

This report outlines and provides examples of the elements necessary to develop a Renewable Energy Community. It also discusses stakeholders that might be involved, and gives details on the systems approach recommended. The elements can be thought of as a progression of stepsnot necessarily in order-but nonetheless building on each other towards such a community. In addition, a literature review and reference list is provided in an Appendix that cites further examples and contact information on stakeholders involved in each particular element.

\footnotetext{
2 "Green developers/builders are often defined as those that use energy efficient appliances and building materials, yet rarely use renewable technologies.” U.S. Green Building Council [cited 2006]. http://www.usgbc.org/. 3 "Renewable Energy Communities" by NREL's definition must use renewable energy technologies. It is a term coined and defined by the NREL authors primarily to differentiate between the term "sustainable communities" that may or may not use renewable energy.

4 Penney, T., and J. Elling. 2006. Plugging In to Renewable Communities. Solar Today 20 (3):22-25.

http://www.solartoday.org/2006/may june06/plugging in.htm.
} 


\section{Table of Contents}

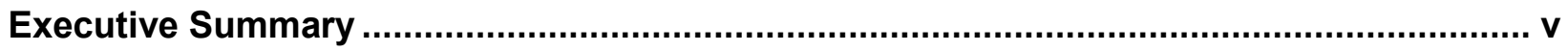

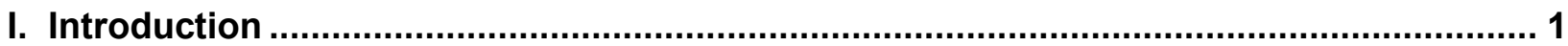

The Problem: Dwindling Supply of Non-Renewable Energy Resources............................. 1

A Solution: Build Vibrant Renewable Communities to Mitigate Energy Supply Issues .......... 1

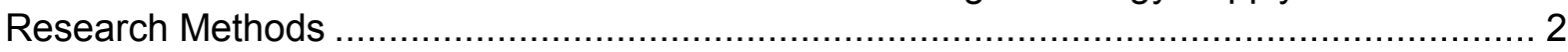

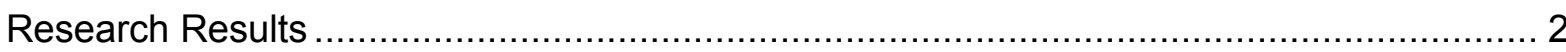

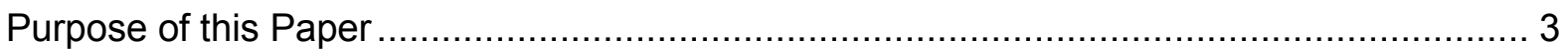

II. Key Elements for a Renewable Energy Community ................................................. 3

1. Sustainable Design Approach................................................................... 3

Examples of Sustainable Design ................................................................... 5

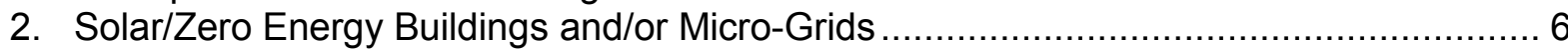

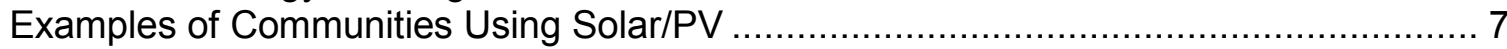

Examples of Communities Exploring Micro-Grids ……........................................ 8

3. Advanced and Energy Efficient Transportation .................................................. 9

Examples of Advanced and Efficient Transportation ............................................. 10

Examples of a Zero-Energy Home with a PHEV ................................................. 12

4. Utility Role Expansion-Power Generation \& Load Management ................................ 12

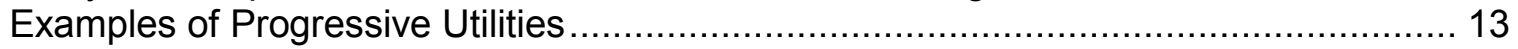

Example of Utilities Interacting with Renewable Community Development .................. 13

5. Putting it All Together for a Renewable Energy Community....................................... 14

Is There a Business Case? .............................................................................. 15

Who Might Finance this Community? .............................................................. 15

Examples of Renewable Energy Communities …………................................... 16

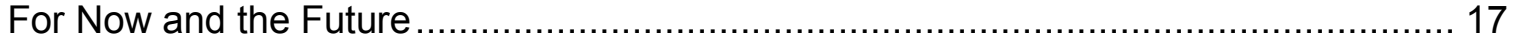

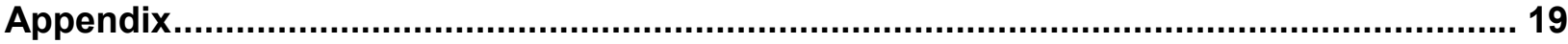

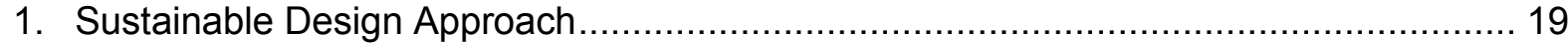

2. Solar/Zero-Energy Buildings and/or Micro-Grids ...................................................... 21

3. Advanced and Energy Efficient Transportation ................................................ 23

4. Utility Role Expansion_-Power Generation \& Power Management ............................ 24

5. Putting it All Together for a Renewable Energy Community..................................... 25 


\section{Introduction}

\section{The Problem: Dwindling Supply of Non-Renewable Energy Resources}

Supplying adequate clean energy to a rapidly industrializing world is one of the 21st century's greatest challenges. Worldwide energy consumption is expected to increase $54 \%$ from 2001 to $2025 .{ }^{5}$ The challenge of providing energy is compounded by concurrent efforts to reduce energy-related pollution and greenhouse gas emissions.

Between 2003 and 2025, the United States' population will grow by 58 million people, ${ }^{6}$ subsequently causing an increase in new building construction. With this growth comes the inevitable growth in consumption of energy, water, food and other non-renewable supplies - unless we change the way we design new communities.

The Renewable Energy Community concept is about advocating innovation-looking at a way to reinvent communities to meet untapped customer needs for shelter and transportation with minimal environmental impacts, stable energy costs, and a sense of belonging.

\section{A Solution: Build Vibrant Renewable Communities to Mitigate Energy Supply Issues}

In 2005, NREL embarked on an initiative to assess the feasibility and understand the barriers of developing Renewable Energy Communities to help America overcome its ever-increasing dependence on fossil fuel and all the associated problems that accompany it.

The Renewable Energy Community, as conceptually defined by NREL, is a state-of-theart community in which integrated, renewable energy technologies play the primary role in meeting the energy supply and demand needs of its residents, with the possibility of providing excess energy back to the grid or other communities. At a minimum, this community will have near-zero or zero-energy homes (ZEHs), integrated transportation modes with advanced vehicles, local renewable energy generation, and incorporate sustainable living practices. The community will provide economic benefits and a positive impact on quality of life. A Renewable Energy Community places added emphasis on the energy element of a "sustainable community" by being powered largely from renewable energy and by integrating power systems for homes and vehicles (see

Integrating the Renewable Energy Community as a whole system can accrue significant benefits. Cost advantages from the systems approach - linking homes with vehicles and addressing energy issues on a community level rather than on individual householdscan be gained compared to the costs of each individual part. Some financial benefits are reduced monthly expenditures with more renewable/energy efficient equipment; tax

5 Energy Information Administration "International Energy Outlook 2004".

6 Heid, Jim. Greenfield Development Without Sprawl: the Role of Planned communities. Urban Land Institute. 
advantages and financial incentives (ex. green bonds ${ }^{7}$ ); and "green" mortgages that incorporate advanced vehicles along with renewable technology.

Developing these communities requires "systems thinking" which is a discipline for seeing wholes. It is a framework for understanding interrelationships rather than individual elements; for seeing patterns of change rather than static snapshots. "Today, systems thinking is needed more than ever because we are becoming overwhelmed by complexity." 8

In this systems approach scenario, new business opportunities will emerge and many industries will benefit including car companies, developers, builders, utility companies, the community itself, and the renewable technology industry. In addition, increasing the amount of renewable energy generation will reduce the use of fossil fuel, our nation's reliance on foreign sources of energy, and subsequently the amount of carbon entering the atmosphere.

\section{Research Methods}

NREL is assessing the feasibility of developing Renewable Energy Communities by drawing on information from several assessment efforts:

- Experience with ongoing collaboration working with several "green" developers grappling with these energy issues

- Survey of builders, developers and stakeholders about their use of and interest in renewable energy technologies

- Literature review and analysis related to Renewable Energy Communities

- Cross-discipline information gathering approach from all NREL renewable energy/efficiency areas.

\section{Research Results}

The research reveals that there is little information available on how to integrate renewable technologies as a system in community building design. Findings revealed only a handful of examples where developers are taking a comprehensive and systematic approach to developing new communities with aggressive energy efficiency and renewable energy goals in mind. NREL's preliminary analysis is showing that a systems approach - linking homes with vehicles and addressing energy issues on a community level versus individual households — can be cost-effective and possibly even profitable. ${ }^{9}$

Energy use in aggregation represents not only a greater demand but also presents new opportunities. For example, analysis on the community system level may identify some technical approaches as optimal, when they are not suited to smaller levels of

\footnotetext{
${ }^{7}$ Green Bonds are an innovative initiative to generate sustainable income for a variety of environmental conscious projects. JP Morgan: http://www.jpmorgan.com/pages/jpmorgan/news/JENIlaunch_Feb07 8 Senge, P. 2006. The Fifth Discipline. 5-22.

9 Penney, T. and J. Elling. 2006. Plugging In to Renewable Communities. Solar Today 20 (3):22-25 http://www.solartoday.org/2006/may june06/plugging in.htm.
} 
aggregation, such as cogeneration, district heating, larger scale wind or solar generation, car-sharing, or changes in land use/zoning.

Research results do show some examples of various renewable and/or sustainable steps that developers are taking, which can ultimately move towards our Renewable Energy Community vision. These examples are included in the paper as well as in an Appendix.

\section{Purpose of this Paper}

To help combat this information and expertise gap, NREL authors created this paper for builders/developers and stakeholders interested in building such a community by outlining the necessary elements to design a Renewable Energy Community using a systems view approach, and including examples of each element and the stakeholders involved. The elements can be thought of as a progression of steps - not necessarily in order-but, nonetheless, building on each other towards such a community.

Understanding the progression inherent in these elements is also a logical way to share the information. The use of the terms "element" and "step" are used interchangeably throughout this paper. A reference list is also provided in the Appendix that cites further examples, stakeholders involved, and contact information (if available). This is not a comprehensive list; it is information that has become available to date to the NREL authors.

\section{Key Elements for a Renewable Energy Community}

NREL has outlined five elements needed to become a Renewable Energy Community:

1. Sustainable Design Approach

2. Solar/Zero Energy Buildings and/or Micro-Grids

3. Advanced and Energy Efficient Transportation

4. Utility Role Expansion-Power Generation and Load Management

5. Putting it All Together for a Renewable Energy Community.

Essentially, each element builds on the other elements to ultimately form a Renewable Energy Community. To date, there are examples of innovation occurring in all five of these elements; however, there are only a few examples that actually begin to put all five elements together to construct a true Renewable Energy Community. Included in the descriptions of each element are some examples, as well as the key stakeholders necessary to make a Renewable Energy Community a reality. These key stakeholders consist of builders; developers; auto manufacturers; utility companies; and local, city, municipal, and federal policy makers. (For additional examples of each element see the Appendix.)

\section{Sustainable Design Approach}

This first step is described as the development of communities for which planners, builders, and developers make a concerted effort to build environmentally compatible, less automobile-dependent developments that attract residents seeking a sustainable 
lifestyle. In general, sustainable design aims to produce places, products, and services in a way that reduces the use of non-renewable resources, minimizes environmental impact, and relates people with the natural environment. In most examples of sustainable communities found in the literature, the energy strategy is primarily about energy efficiency.

For the Renewable Energy Community, sustainable design can reduce energy use for both buildings and transportation.

For buildings, efficient home design and orientation can reduce the need for building energy use before ever buying any energy equipment by maximizing the use of passive solar design (to minimize solar gain in warm climates, and maximize in cool climates), daylighting, and natural ventilation and shading. There are many degrees of sustainable design that can be applied to individual buildings andlor communities. For instance the Packard Foundation identifies six categories of buildings ranging from the "market building", defined as a conventional building, to a "living building", defined as one that has a net zero annual impact on the environment from an operational standpoint. ${ }^{10,11}$

Similarly, for transportation, efficient community layout that places schools, shops, and other services close to homes and business, making it easy to get places without driving and offering attractive bicycle and walking paths, can greatly reduce vehicle miles traveled per household. This would in turn reduce the amount of energy needed for transportation - while improving quality of life — even before any expenditures are made for vehicles.

These are all elements that can contribute significantly to decreasing the conventional energy requirements of a home or building. In general, these communities aim to include attributes such as:

- Energy efficient construction (i.e. building envelope, HVAC systems, and appliances)

- Passive solar design and lot positioning

- Community layout to reduce vehicle use, increase walkability, and provide access to mass transit

- Recycling and water conservation

- Ecological integrity

- Social equity

- Cultural and historical vitality.

\footnotetext{
${ }^{10}$ Packard Foundation. 2002. Building for Sustainability Report. Available at: http://www.hpsarch.com/TitlePageSpecial/2002-Report.pdf

${ }^{11}$ In between the "market building" and the "living building", the report defines four other buildings meeting various levels of sustainable design. http://www.bnim.com/fmi/xsl/research/packard/index.xsl.
} 


\section{Examples of Sustainable Design}

There are many examples of communities that embrace some degree of sustainable design, implemented through a variety of planning techniques such as "new urbanism"12, conservation development, and transit oriented development.

The U.S. Green Buildings Council Leadership in Energy and Environmental DesignNeighborhood Development (LEED-ND) ${ }^{13}$ certification program recognizes these "green" neighborhoods. The objective of these approaches is to design communities that make a concerted effort to build environmentally compatible, less automobile-dependent developments; integrate living, working, shopping, and socializing; and attract diverse and heterogeneous residents in terms of age, culture, family type, income levels, and other factors. These types of neighborhoods are described as sustainable in the sense of placemaking. It is more challenging to find examples of communities that meet not only these sustainable design principles, but also include solar (passive) use.

- Geos Living, Arvada, CO. This development, currently in the planning stage, was recently awarded an American Institute of Architects Denver chapter honor award for its site planning. This neighborhood combines sustainable site planning, sustainable building technology, and energy performance standards to create a neighborhood that is "net-zero-energy ready" for its residents.

The site is 20 acres with 260 planned mixed use housing units. It is located close to regional shopping and employment and along a bikeway, which leads to the Rocky Mountains and towards downtown Denver. Building placements were analyzed by comparing various density alternatives against requirements for solar access. It was recognized that the use of passive solar design principals would greatly reduce building heating and cooling loads on individual homes to maximize winter solar gain and minimize summer solar gain. The development pattern is nicknamed "checkerboard" because homes are staggered on the lot to allow for solar access.

Ground materials and landscaping are designed to maximize earth permeability and reduce heat gain. Linear greens, sometimes replacing streets, filter storm runoff and bind a community together through a diverse pedestrian, park and drainage network. Small shops, live-work spaces, public gathering areas, and the bikeway are accessible via tree-lined walkways from every home, minimizing the need for commutes. The buildings are planned to use R-30 walls; superior air infiltration values and air-to-air heat exchangers; "earth tubes" for tempering fresh air supply; higher levels of thermal mass; neighborhood-wide geothermal heat source; and photovoltaics (PV) on most homes roofs ${ }^{14}$

$12 \mathrm{http://en.wikipedia.org/wiki/Examples} \mathrm{of} \mathrm{New} \mathrm{Urbanism.}$

13 http://USGBC.org.

14 Taken from AIA Colorado, 2006 Annual Denver honor awards. http://www.aiacolorado.org.

Information on this project can also be found on the Discovergeos.com web site. 
- Dewees Island, S. Carolina. Another highly visible example of environmental consciousness is the Dewees Island project. A high-end retreat community of 150 homes clustered on the least environmentally sensitive portion of a 1,200-acre island, Dewees is designed with environmental preservation as a primary goal. Builder guidelines include requirements for energy-efficient design and appliances, construction waste management, and use of environmentally responsible building materials. The developer of Dewees Island is now undertaking a major redevelopment of the 3000 acre Navy Yard in Charleston, S.C. under a public-private partnership. The development, called Noisette, the New American Community, is being designed and built using sustainability principals. The developer is planning for energy efficient buildings, the use of district cooling and renewable energy, along with the use of recycled materials, innovative stormwater management and water reuse strategies.

\section{Solar/Zero Energy Buildings and/or Micro-Grids}

Building on the sustainably planned communities in step one includes incorporating renewable energy technologies, such as solar/photovoltaics (PV) on rooftops, to become solar/zero-energy homes, or a community-based, renewable power generation system (microgrids).

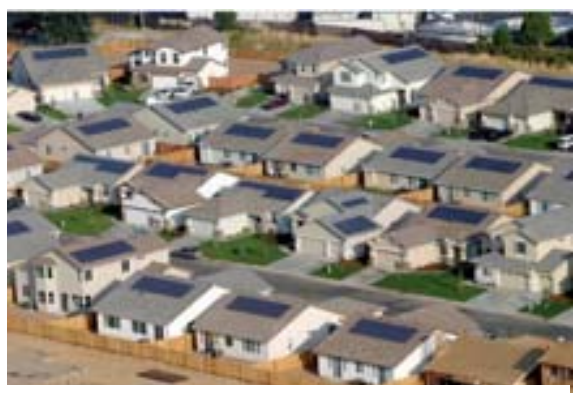

What's a ZEB cost and who's willing to pay?

NREL has developed data on the added cost of net zero homes in various locations throughout the U.S. and has compiled survey results on consumer attitudes and the premium consumers are willing to pay for various renewable and energy efficiency features in new housing. Check out two papers:

(1) "Analysis of Residential Systems Targeting LeastCost Solutions Leading to Net Zero-energy Homes", and

(2) "A New Market Paradigm for Zero-Energy Homes: The Comparative San Diego", at: www.nrel.gov/publications.

Zero-energy Homes Community Premier Gardens, Sacramento

Zero-energy buildings (ZEBs), as conceptually defined by the U.S. Department of Energy (DOE), are "residential or commercial buildings with greatly reduced needs for energy through efficiency gains, with the balance of energy needs supplied by renewable technologies" ${ }^{15}$. Most ZEBs feature solar on the roof and energy efficient construction to reach net-zero-energy use.

Through the Building America private/public partnership the U.S. DOE has supported construction of more than 30,000 zero or near-zero net energy homes, seeking at least $50 \%$ utility bill savings and collected data on their cost-effectiveness. Many of the larger home developments are in California, because of a combination of state and local rebate and other incentive programs for renewable energy, but others have been built around the

15 Malin, N.; Boehland, J. "Getting to Zero: The Frontier of Low-Energy Buildings." 14 (10).

www.BuildingGreen.com. 
country and the world as well. Most feature rooftop solar electric PV generation in addition to energy efficient construction.

Micro-Grids (or community based renewable power generation systems) can use centralized or decentralized sources of power. For example, the power source could be a wind farm, solar thermal generating station, PV field, or other central facility located near the community. Power could also come to the micro-grid from rooftop PV, small wind turbines, or other decentralized power generators distributed throughout the community, but connected. A micro-grid requires energy storage devices or use of the grid as backup power. Renewable micro-grids may be a key element to provide adequate power for the future through renewable and other clean energy sources that will not degrade air quality. (See Table 1 below for a comparison of central versus distributed approach to renewable energy generation.)

\section{Examples of Communities Using Solar/PV}

There are many examples of these types of home developments:

- Pardee Homes has built hundreds of homes in Southern California and the Las Vegas, Nevada area. ${ }^{16}$

- GrupeGreen's Whitney Ranch development in Rocklin, California offers 144 homes promising utility savings up to $70 \%{ }^{17}$

- Clarum Homes' Vista Montana development was so well received that they are now building only zero-energy homes with solar in the San Francisco and Southern California and Arizona desert areas. ${ }^{18}$

- Premier Homes, in Sacramento, California, in conjunction with the utility district, built 95 homes designed to save $60 \%$ on utility bills. ${ }^{19}$

- Solar Village, Prospect New Town, Longmont, Colorado, is a mixed use green built village of condos, lofts, flats, a yoga studio, ice cream parlor, and a high-end restaurant. It includes solar assisted radiant floor heating, efficient lighting and appliances, passive solar design, and energy efficient building materials. It claims electric and gas bills that average \$20 per month because of these efficient and renewable features.

- Chula Vista, California Research Initiative. The goal of this research initiative is to develop a model process and designs for energy-efficient community development from initial planning to final build-out for three new communities. Each design will seek to maximize opportunities for the integration of renewable energy; distributed generation; demand response technologies; energy efficiency in residential, commercial, industrial, and institutional structures; and in supporting municipal infrastructure and services. Additionally, the designs will feature smart growth land

$16 \mathrm{http}: / / \mathrm{www}$. forester.net/de 0503 taking.html.

17 http://www.grupe.com/communities/carsten/features.cfm.

$18 \mathrm{http}: / /$ clarumzeroenergy.com/.

19 http://www.solartoday.org/2005/may june05/ZEH.htm. 
use planning and green building design elements that will maximize the performance of these technologies while reducing the urban heat island effect and emissions of greenhouse gases and regulated pollutants.

- Army Hawaii Family Housing (AHFH) at Schofield Barracks, Oahu, Hawaii. Actus Lend Lease developer, in partnership with the Army, is installing enough photovoltaic panels on the homes to generate $7 \mathrm{MW}$ of electricity, in addition to solar hot water and other aspects of energy efficiency. The photovoltaics panels will offset approximately $30 \%$ of the communities' electrical needs. When completed the $\$ 2.3$ billion Army Hawaii Family Housing community will include 5,388 new homes and the renovation of 2,506 existing homes in seven sites around Oahu. This was initiated by the Military Housing Privatization Initiative (MHPI) in an effort to provide a better quality of life for service members and their families. According to the office of the Under Secretary of Defense, soldier retention is $15 \%$ higher for those stationed on installations with superior housing and community life. ${ }^{20}$

\section{Examples of Communities Exploring Micro-Grids}

- Sonoma Mountain Village, Rohnert Park, California. This community is sited on a 200-acre former business campus site that is being converted to a mixed use development. The community has incorporated a centralized 1.14 MW photovoltaic rooftop power plant. ${ }^{21,22}$

- BioTown, Reynolds, Indiana. The existing town of Reynolds, Indiana, has declared itself "BioTown," seeking initially to have the highest per capita use of ethanol, biodiesel, and flex-fuel vehicles.

Longer-range plans though include meeting the town's energy needs by using agricultural residues and municipal waste to produce both electricity and natural gas.

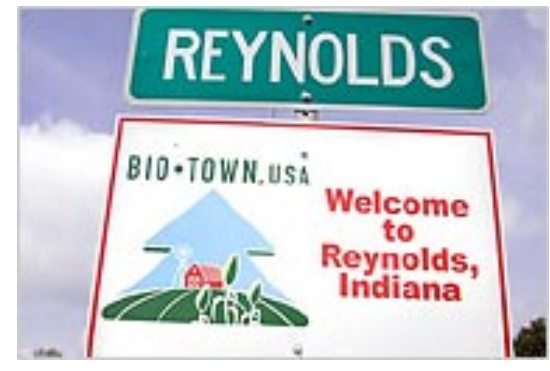

- Drake Landing Solar Community, Alberta, Canada. Drake Landing shares communal renewable resources using a solar-heated district space and water heating system mounted on the garage roofs to serve all 52 homes in the community. In addition to short-term storage, the system will store extra heated water from the summer in boreholes in the ground for use in the winter. ${ }^{23}$ The system is expected to meet more than $90 \%$ of space heating.

20 http://www.bovislendlease.com/llweb/all/main.nsf/all/fp hawaii

21 North Bay Business Journal. (Jan. 2007). The Future has an Address.

http://sonomamountainvillage.com/home.htm.

22 A 1.14 MW photovoltaic rooftop power plant can generate $1140 \mathrm{~kW}, 1446 \mathrm{kWh} \backslash \mathrm{yr}$ or 1,648,440 million $\mathrm{kWh}$ lyr. If you assume that one house uses an average of $500 \mathrm{kWh} \backslash$ month, this would equal the electricity requirements of about 280 homes.

23 http://www.dlsc.ca. 
Table 1. Comparing a Central versus Distributed Approach to Renewable Generation

\begin{tabular}{|c|c|}
\hline \multicolumn{2}{|c|}{$\begin{array}{c}\text { Pros and cons of central versus distributed approach } \\
\text { to community-based renewable generation }\end{array}$} \\
\hline Distributed Systems & \\
\hline Pro & Con \\
\hline $\begin{array}{l}\text { - Consumers in homes with renewable } \\
\text { energy generating systems tend to conserve } \\
\text { more } \\
\text { - No transmission or distribution losses } \\
\text { - For new construction, the cost of the } \\
\text { home's renewable energy system can be } \\
\text { included in the homes construction cost } \\
\text { and therefore in the mortgage }\end{array}$ & $\begin{array}{l}\text {-Individual maintenance } \\
\text { • Home layouts need to consider } \\
\text { orientation for PV }\end{array}$ \\
\hline \multicolumn{2}{|l|}{ Central Systems Serving Community } \\
\hline Pro & Con \\
\hline $\begin{array}{l}\text { - Lower cost than distributed systems } \\
\text { - Could be wind, biomass, etc. based } \\
\text { PV can be } 1 \text {-axis tracking which produces } \\
30 \% \text { more energy than fixed PV } \\
\text { - Central O\&M and performance } \\
\text { monitoring } \\
\text { - Can double as an amenity (such as } \\
\text { shading a parking structure) } \\
\text {-Maintained by technology experts }\end{array}$ & $\begin{array}{l}\text { - Transmission and distribution losses } \\
\text { - May require land (unless installed on } \\
\text { top of parking or other structure) } \\
\text { - Metering to credit individual homes } \\
\text { can be more difficult }\end{array}$ \\
\hline
\end{tabular}

\section{Advanced and Energy Efficient Transportation}

In parallel with the first two steps includes adding a key technology element-advanced vehicles (electric, hybrid, plug-in, or alternative fueled vehicles) and energy efficient transportation (mass transit, car sharing). Integrating advanced vehicles and energy efficient transportation with sustainable buildings is a major paradigm shift to allow the development of cost-effective Renewable Energy Communities. How so?

As previously mentioned, the sustainably designed community ideally focuses on reducing vehicle miles traveled through the use of efficient community layout, bicycle and walking paths, easy access to mass transit, and possibly car sharing. These are relatively easy ways to first eliminate unnecessary energy use for transportation.

Another step to reduce fossil fuel use for a Renewable Energy Community includes incorporating advanced vehicles. One type of advanced vehicle to focus on is a plug-in hybrid electric vehicle (PHEV) that builds on today's electric powered vehicle. Promising to come to market within a few years, PHEVs are essentially hybrid electric vehicles (HEVs) with added (more expensive) battery capacity. They can be fueled at home by plugging in to an electric outlet, where the electricity can be generated from renewable energy either located on the home or available from the local utility. The needed gasoline could also be replaced by ethanol or other renewable derived fuels. This PHEV technology offers lower fuel costs (about 3 cents per mile driven on electric power versus 
12 cents per mile driven on gasoline power), home refueling (fewer trips to the gas station), and reduced tailpipe emissions. As little as 20-mile-all-electric range in battery capacity would make a huge difference in gasoline use as most people drive less than that each day. For longer trips, once the batteries are drawn down, the PHEV would operate like a regular hybrid.

Connecting these advanced vehicles to a home in a Renewable Energy Community is important because PHEVs (or electric vehicles) could be connected to a utility grid in two directions both distributing and accepting electricity. And the next-generation PHEV will have the ability to store excess electricity for timely return to the grid. We call this "two-way" plug-in a vehicleto-grid (V2G). Utilities spend a tremendous amount for capacity to continuously balance supply and demand across the grid or provide

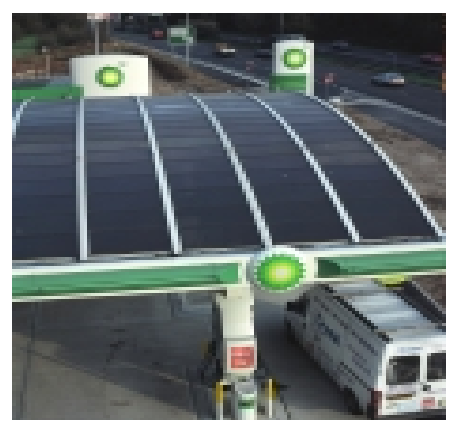

British Petroleum solar car park. Courtesy of BP. backup electricity during outages and peak-demand periods. Because batteries provide this kind of service, which is so critical to utilities, they might pay V2G owners to "borrow" energy-storage capacity. (using "smart grid" connections - see sidebar). Combined with fuel savings, this income could pay back the more expensive battery cost within relatively few years. Vehicle owners might also benefit from differential rates for off-peak charging and peak contribution to the grid.

Builders can easily design homes to be "plug-in ready" for today's available electric vehicles (mostly neighborhood electric vehicles) or the coming PHEVs.

\section{Examples of Advanced and Efficient Transportation}

- Car sharing and mass transit. While not a magic bullet to solve all traffic and air quality problems, especially commuter-related issues, car sharing and mass transit are important tools that can quickly deliver real benefits from primarily market-based capital. Car sharing is essentially a network of privately owned vehicles that are rented by the day or by the hour. Cities like Seattle and Washington, D.C., have strong transit support for car sharing. Philadelphia and Berkeley have replaced part of their city fleets with car sharing and other cities are providing on-street and other parking support. Washington D.C.'s Department of Transportation locates car sharing kiosks near Metro stations and neighborhood centers. For an annual fee of roughly $\$ 25$ and an hourly fee of about $\$ 8$, residents can obtain the use of a car without the large costs associated with owning one. The hourly charges cover insurance, fuel, maintenance, and the rental rate. Experiences in other cities, as well as independent 
studies, show that a single car sharing vehicle can be used by 6 to 10 households and can help reduce parking and traffic congestion.

As for mass transportation in the U.S., its use has declined. Only in U.S. cities of more than two million people does the mass transportation share reach or exceed $10 \%$ of the trips. ${ }^{24}$ However, mass transit when well utilized can produce important benefits for a community including: air-quality improvements, less land consumption than auto-dependent transportation systems, lower energy requirements, and lower accident costs. Mass transit powered by renewable energy sources could provide even greater benefits.

- Global Electric Motorcars (GEM) neighborhood electric vehicles (NEVs). Although there are limited full-use electric vehicles readily available for the average American consumer, presently GEM (a division of Daimler Chrysler) is successfully selling limited-use NEVs. While the immense popularity of HEVs is opening the door for plug-in hybrids that could operate much of the time on electric power, NEVs are a good model for how renewable energy vehicles could be integrated into Renewable Energy Communities. Built for low-speeds and short-distances, NEVs are marketed primarily for use within communities. The cars are charged by plugging them in to a regular 110 outlet. They are an integral part of the design and infrastructure of several new communities in Michigan, Florida, and California, and are intended to be used mostly for local travel within the communities. In Bay Harbor, Michigan, the GEM cars were included as part of the purchase price of many of the houses. In Playa Vista, California, there will also be a fleet of GEM cars available on a car sharing, per-trip use basis.

- Plug-in hybrid-electric vehicles. PHEVs are not yet available from automotive manufacturers, but several start-up companies are converting regular hybrids to plugins. The popularity of the regular hybrids, together with enthusiasm for the plug-ins, suggests that commercial production shouldn't be far away-both Ford Motor Company and General Motors introduced concept plug-in hybrids at the Detroit Auto show in 2007.

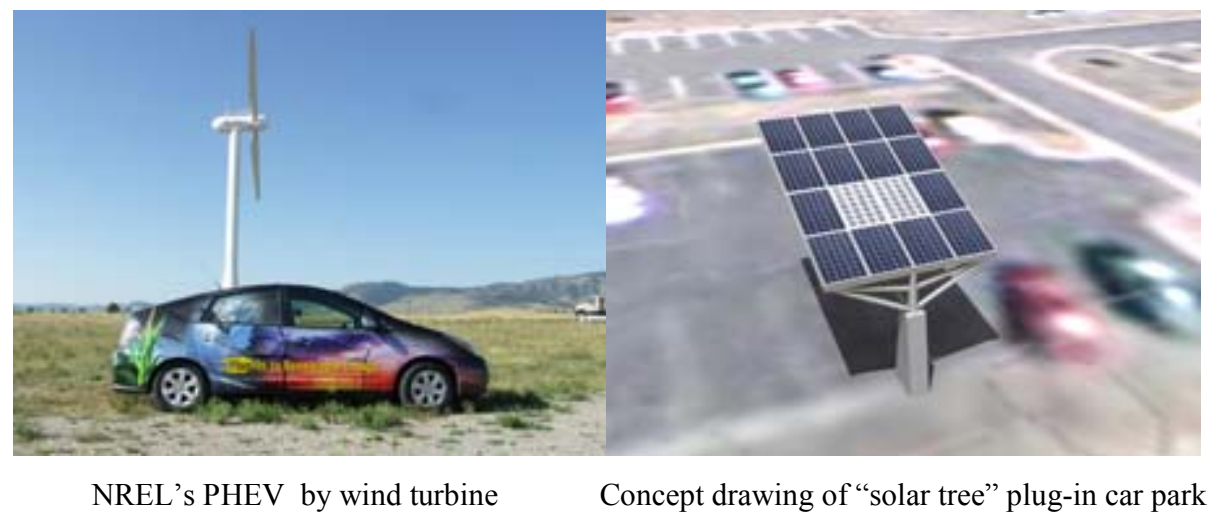

24 http://www.britannica.com/eb/article-64257/mass-transit. 


\section{Examples of a Zero-Energy Home with a PHEV}

- The Toyota Dream House, Aichi Prefecture, Japan. This particular zero-energy house has been designed specifically to accommodate plug-in vehicles. The Toyota Dream House ${ }^{25}$ in Japan was designed primarily to showcase a computer-controlled operating system for the house (Toyota has home building as well as automotive divisions), but it also includes efficiency measures, a PV system, and a charging connection for a plug-in version of the Toyota Prius HEV. Interestingly, the connection is "two-way" so the vehicle batteries can provide emergency power to the house in the event of a power outage.

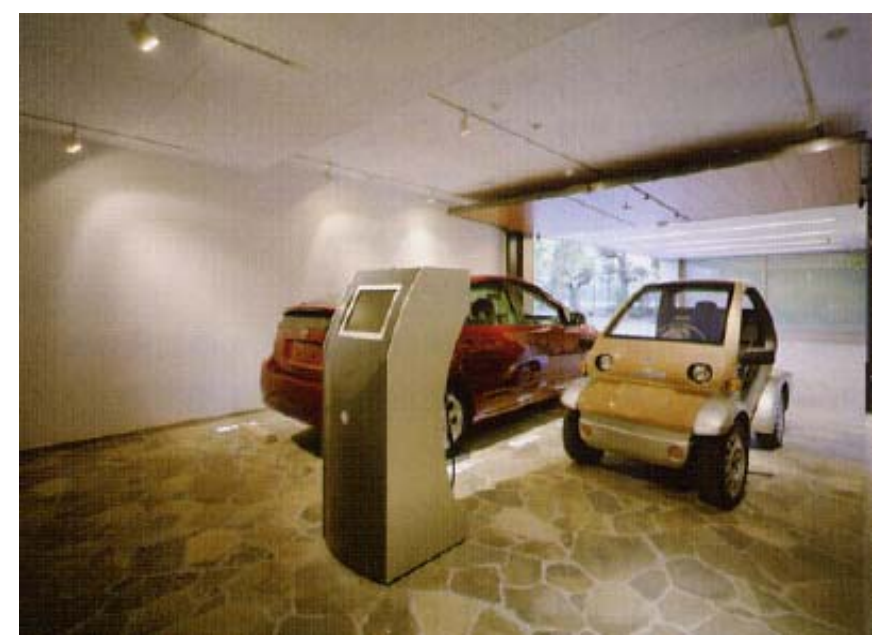

Plug-in vehicles to Toyota's Dream House.

Picture courtesy of Toyota.

- Hybrid Technologies, Nevada. This company makes lithium-ion battery-powered products, but is embarking on building a total zero-energy home (including energy efficiency, wind, PV, and geothermal heat pumps) in Alberta, Canada, which will include charging facilities for the electric cars and motorcycles that it makes. ${ }^{26}$

\section{Utility Role Expansion-Power Generation \& Load Management}

Taking another step towards becoming a Renewable Energy Community includes expanding the role of local utility companies to maximize renewable energy economies of scale. As the nation increases reliance on renewable energy, more distributed renewable power generation on the utility grid will allow communities to take advantage of the renewable energy economies of scale. Many utilities see renewable energy generation at the community level (the creation of "micro-grids") as a key element to providing adequate power for the future that will not degrade air quality. Renewable energy micro-grids with decentralized management and control offer increasing degrees of grid reliability, stability, and resiliency in the face of power outages. ${ }^{27}$ A Renewable Energy Community with such a micro-grid could be less vulnerable when major outages

25 http://tronweb.super-nova.co.jp/toyotadreamhousepapi.html.

26 www.hybridliving.com.

27 EPRI, 1/30/2006. "Sustainable Communities-Business Opportunities for the Electric Utility Industry," http://my.epri.com/portal/server.pt?. 
do occur. In addition, adding community-based generating systems could avoid the need to build additional transmission lines or new central generation facilities - affording substantial cost savings. In this situation the role of the utility may expand over time to include both power management and power generation (exporting and importing power). Utilities may become key stakeholders in the development of Renewable Energy Communities.

PV rooftops systems. Linking PV systems at the community level can offer some of the economies of scale of utility-scale PV applications. Many of these PV applications are already cost-effective for certain markets, as previously discussed. For example, in order to handle increasing demands for daytime electricity, San Diego Gas and Electric choose to develop a PV peaking station in an outlying San Diego suburb in lieu of upgrading the more distant generating plants and distribution system to the suburb. Integrating PV clusters in a community format can reduce or eliminate sitting costs altogether, and additional efficiency can be gained if excess power can be exported to another homeowner, business, or community that has a need for it at the time of generation. At the community level, a power generation micro-grid provides a way to share electricity or other energy generation and use within the community, between communities, or with the main utility grid.

PV/zero-energy homes and vehicle systems. An example of a distributed generation micro-grid will be connecting advanced PHEVs (step three) and solar/net-zero-energy houses (step two) with the main utility. As previously discussed, this plug-in vehicle-togrid role will allow the vehicle/home owner and the utility to take advantage of the extra electrical storage capacity in the vehicle's battery to meet peak demand, provide grid support services, or respond to power outages. The vehicle and homeowner can further benefit if the utility compensates the vehicle owner for "borrowing" the battery capacity. Utilities can benefit by saving on the need for ancillary, quick-response services and increasing the grid's stability and reliability.

\section{Examples of Progressive Utilities}

Already many utility companies are making strides towards helping Renewable Energy Communities become a reality. For example, Austin, TX, Sacramento, CA, Minnesota, and Wisconsin have been at the forefront of renewable energy advocacy and their municipal utilities have played key roles. All these utilities stand out from the crowd because their net metering rules allow participants to be paid the going retail rate for the net excess electricity they generate for each billing cycle. ${ }^{28}$ Other utilities around the country are soon to join in improving their net metering rules.

\section{Example of Utilities Interacting with Renewable Community Development}

- Austin City is studying the possibility of adopting a series of code changes that will make all new single-family homes built in the City's building code jurisdiction "ZeroEnergy Capable Homes" by the year 2015. Austin Energy utility now generates 11\% (goal 20\%) of its electricity from renewable sources and is developing a plan for

28 EPRI, 1/30/2006. "Sustainable Communities—Business Opportunities for the Electric Utility Industry," http://my.epri.com/portal/server.pt?. 
rebates for PHEVs. Because its nighttime electric demand is only $50 \%$ of the afternoon load, its system could easily accommodate and benefit from overnight vehicle charging.

- The Japan Area Home Builders Network in Japan has built a model standardized home that totally eliminates utility cost by being able to sell electricity back to the grid equivalent to the cost of grid electricity that it does use. ${ }^{29}$

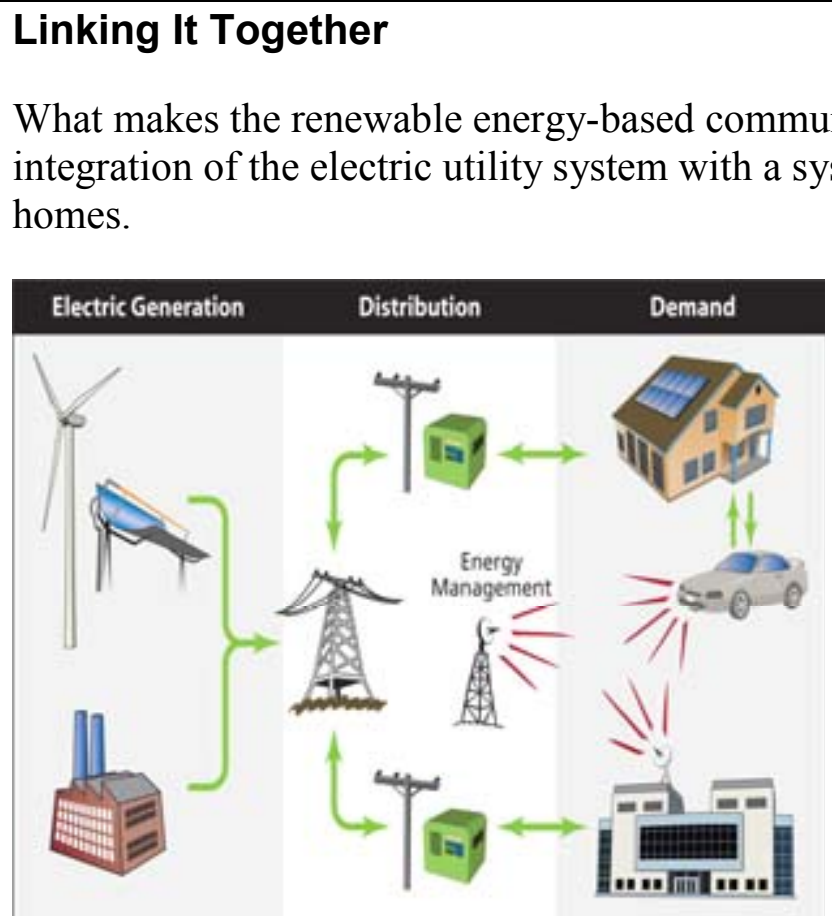

Source: Dean Armstrong, National Renewable Energy Lab
This interconnected energy system can flow two ways, as shown by the arrows in this graphic. A "two-way" plug-in hybrid vehicle (also known as a vehicle-to-grid, or V2G, vehicle) is plugged into an electric outlet in the garage of the home or workplace, allowing electricity to flow from the energymanagement system (traditionally the grid) to the vehicle and vice versa.

An energy-management operator can broadcast a control signal to any number of V2Gs (including fleets) to give or request electricity. Each vehicle's smart control system monitors its ability to give and receive electricity and communicates this information with the operator. Electric generation could come from a traditional power plant or renewable sources such as wind turbines or solar plants.

\section{Putting it All Together for a Renewable Energy Community}

Developing a Renewable Energy Community requires that we plan developments that integrate all four of the elements previously discussed in this paper. We need to scale up what we already know how to do-place an increasing emphasis on energy efficiency, embrace energy conservation, and use significantly more renewable energy using a systems approach. This is an opportunity to demonstrate that we can have vibrant communities that use significantly less conventional energy. It will require that we "reinvent" how to meet our nations need for housing and transportation by viewing energy systems for homes and vehicles as one integrated system connected to a utility and lor a distributed power generation network.

$29 \mathrm{http}: / /$ www.insnet.org/ins_headlines.rxml?cust=2\&id=1854\&url=http://www.japanfs.org/db/ database.cgi? $\mathrm{cmd}=\mathrm{dp} \& \mathrm{n}$ um $=1136 \& d p=$ data_e.html. 
As part of the design process for the new community, stakeholders will need to address how energy will be generated and used for both homes and cars. This will require collaboration between stakeholders including developers, local utilities, homebuilders, local governments, and automobile manufacturers. Classic business models will be retooled to offer new partnership opportunities, and players will need to rethink their traditional roles. Through this approach, all parties will face not only technical and economic questions, but also questions of national and local values and priorities. The reinvention of communities will require that developers and other stakeholders make financial investments in infrastructure that will be different than in the past. Public policy will also be key to eliminate barriers that make it challenging to incorporate greater levels of renewable energy generation and energy efficiency into communities.

\section{Is There a Business Case?}

Energy-efficient homes, PV systems, solar hot water, geothermal heat pumps and other energy efficiency technologies are offered by many homebuilders or suppliers. Commercially available plug-in hybrids are just a few years away. Integrating multiple energy systems is the key and the technology to do so is available today; yet cost, risk, consumer demand, "it hasn't been done yet", and other issues cause businesses to pause at the opportunity. NREL experts have begun to look at these issues by analyzing a number of Renewable Energy Community scenarios that link transportation, homes, and the electric grid, as well as enable large quantities of renewable power onto the grid. Preliminary analyses show that the homeowner would gain a net cost advantage by

\begin{tabular}{|l|}
\hline A Business Case Example \\
Typically a near-zero-energy home with PV \\
panels and energy-efficient measures can be \\
expensive, raising the initial cost of this home. \\
However, examples show that when included \\
in original construction cost, and in the home \\
mortgage, energy use can be significantly \\
reduced with no increase in total monthly bills. \\
For instance, a U.S. DOE handbook for hot \\
and humid climates posed an example of \\
spending an additional $\$ 1,500$ for an \\
ENERGY STAR home (including various \\
energy-efficiency features, but not PV or a \\
geothermal heat pump). For an additional \\
mortgage cost of only $\$ 9$ per month, energy \\
bills were reduced $\$ 40$ per month - for net \\
savings of $\$ 31$ per month. Added PV \\
electricity-generation and other energy- \\
savinas features will be "baid back" in home \\
\hline
\end{tabular}
integrating a zero-energy home with a PHEV.

Although there are a number of variables that affect this calculation, the economics of the integrated system are substantially better than an analysis of each piece individually would suggest. And, based on energy forecasts, investments in these communities may act as hedge against future high energy costs, and ultimately capture a growing market demand for a new approach to housing, cars, and energy use.

\section{Who Might Finance this Community?}

Because renewable energy facilities and advanced vehicles generally involve additional upfront capital expenditures - but will often pay for themselves over time - there are a number of intriguing possibilities for financing a Renewable Energy Community. For instance, community-level "car-share" renewable-fueled vehicles can easily be owned by a neighborhood association or utility. Homeowners pay nothing up front-paying for the energy or vehicle cost only as they use them.

Another opportunity could be to involve an energy performance service company (EPSC) similar to those that currently serve commercial or government buildings and facilities. 
The EPSC would operate by installing the renewable energy facility or providing the car fleet (generally financed by a third-party investor), then charging the community in accordance with how much lower its utility bill is versus what it would have been without the additional facilities. In any of these arrangements, the main-grid utility might provide beneficial terms because of the impact the communal facilities have on reducing peak demands, increasing off-peak use (such as charging electric vehicles over night), or providing extra energy to the grid to meet peak demand. Such utility agreements can likely be much better negotiated by community facilities than they could be for individual homeowners. Green bonds, utility energy savings contracts, and partnerships are examples of other ways to leverage financing for Renewable Energy Communities.

\section{Examples of Renewable Energy Communities}

To our knowledge, a Renewable Energy Community, as defined by NREL, has yet to be created. But, many developments go a long way towards the goal and there are ambitious plans in the works.

- Beddington Zero-energy Development (BedZED), England. BedZED is being designed to be carbon neutral, with strong emphasis on roof gardens, sunlight, solar energy, reduction of energy consumption, and waste water recycling. BedZED provides about 100 mixed-use homes with a green transport plan that promotes walking, cycling, and the use of public transport, including a car pool for residents.

- Dongtan, Shanghai, China. This sustainable city of 80,000 people will include a 33-MW electrical generating plant using rice-husk

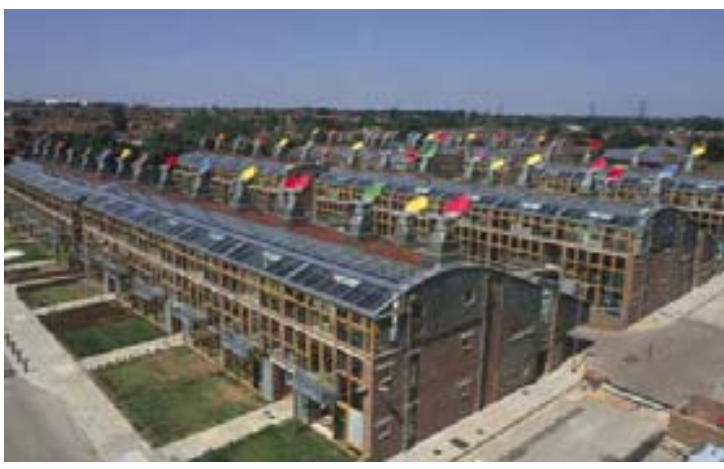

BedZED building in progress. (c) Arup/Graham Gaunt agricultural residue as a feedstock, together with a district heating system using the waste heat from the plant, to meet all of the city's water, space heating, and cooling needs. It is a former agricultural 1,600-acre river island. High density (mostly 6-8 story apartments), along with adjacent location of the power plant, will make the district heating system possible and also reduce the need for car access and energy use for transportation. ${ }^{30}$

30 http://www.arup.com/eastasia/project.cfm?pageid=7047. 


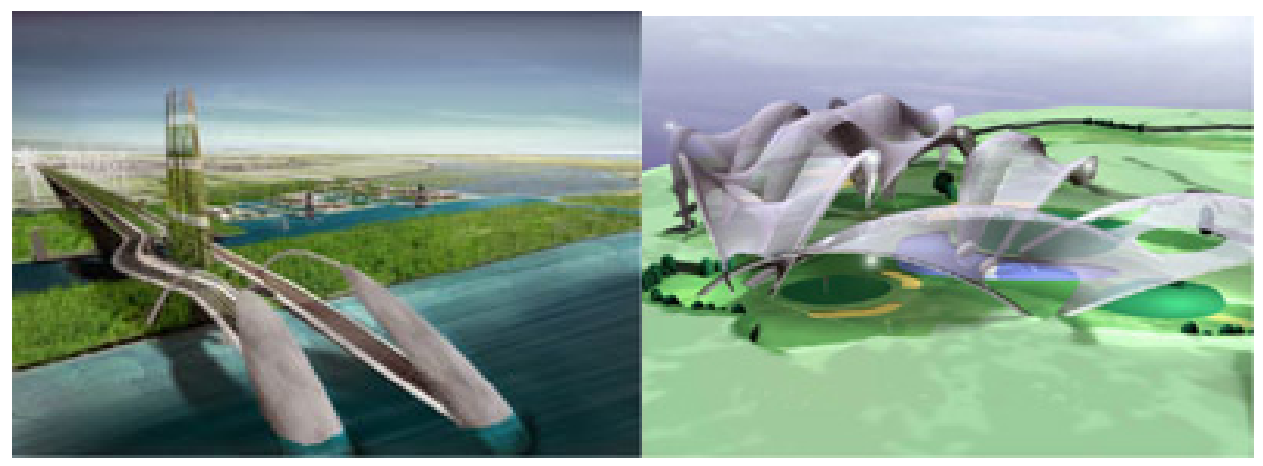

Conceptual drawings of Dongtan, China. Pictures courtesy of China government.

- Samsoe Renewable Energy Island, Denmark. This island provides $70 \%$ of its heat with four district heating plants on the island, plus several private heating systems burning plant oil. Gradually, islanders are increasingly using biodiesel for liquid fuels. For electricity, islanders installed 15 new wind turbines. The turbines on land are owned individually by local farmers. To compensate for liquid fuels used in transportation, the islanders installed ten $2.3 \mathrm{MW}$ wind turbines offshore; two of which are cooperatively owned by 450 shareholders. There are about 4,500 residents on the island.

- Sarasota, Florida. Sarasota County announced on June 10, 2006 the creation of the nation's first national renewable community in recognition of the county's commitment to developing an energy efficient community that will be sustainable far into the future. To help achieve this future community, a partnership was formed between Sarasota County government officials, home builders, Florida Power \& Light Co., and the National Renewable Energy Laboratory.

- Destiny USA, Syracuse, New York. On a 250-acre redevelopment site in Syracuse, Destiny USA is planned as a 75-million-square-foot, 25,000/60,000-room hotel/commercial/retail/transportation/entertainment "retail city" convention center complex. The project is supported by a Federal Green Bond, in accordance with which the developers are committed to building the complex to operate without fossil fuels. To achieve this, they plan to use a variety of technologies including solar and biodiesel electric generation onsite, wind (both built and purchased) offsite, natural gas fuel cells, PV, and GEM neighborhood electric vehicles. The largest retail mall in the world will showcase its renewable energy use for its anticipated nearly 40 million visitors per year, of which one in ten are expected to come specifically to see the green and renewable energy technologies. Construction is just starting and developers plan to complete the project in about 5 years.

\section{For Now and the Future}

As can be seen from all these elements and examples, the steps are largely available today to build Renewable Energy Communities using a systems approach, with PHEVs just a few years away. The economics will increasingly become competitive with conventional development, especially as future renewable energy technology develops and becomes mainstream. Buildings integrated with photovoltaics, electrochromic 
windows, light-emitting-diode light fixtures, and structural insulated panels can be used to improve home efficiency; fuel cells can replace the gasoline/ethanol engines in the plug-in hybrids; and excess wind turbine power or gasified biomass can be made into hydrogen.

Taking Renewable Energy Communities to the ultimate zero-energy footprint in the future will include accounting for both direct and indirect energy use (energy embodied in the community's imported goods, such as food, water, building materials, etc) to a community. The ultimate goal is to become a self-sustaining community with zero carbon, zero waste, sustainable transportation, sustainable materials, local and sustainable food, sustainable water, natural habitats and wildlife, culture and heritage, equity and fair trade, and, of course, health and happiness. 


\section{Appendix}

\section{Information Review for a Renewable Energy Community}

\section{Overview}

The purpose of this information review is to provide some existing and future concept examples and links for each of the five elements/steps towards developing a Renewable Energy Community, as outlined in the main paper, which include: 1. Sustainable Design Approach, 2. Solar/Zero-Energy Buildings and/or Micro-Grids, 3. Advanced and Energy Efficient Transportation, 4. Utility Role Expansion-Power Generation \& Power Management, and 5. The Renewable Energy Community-Putting it All Together. The examples given in the main paper are also provided in this review. This appendix is not a comprehensive compilation and should be viewed only as an initial resource for stakeholders interested in building a Renewable Energy Community. Web site links are provided when available.

\section{The Sustainable Design Approach}

This first element is described as the development of communities for which planners, builders, and developers make a concerted effort to build environmentally compatible, less automobile-dependent developments that attract residents seeking a sustainable lifestyle.

\subsection{Information review sources}

- The U.S. Green Building Council, www.usgbc.org. Leadership in Energy and Environmental Design-Neighborhood Development (LEED-ND) certification program recognizes these "green" neighborhoods. Currently there are 238 developments that are participating in a pilot project to seek certification and help to test the Neighborhood Development rating system.

○ www.usgbc.org/Nrew/PressReleaseDetails.aspx?ID=3304, the LEED for Neighborhood Development Web page.

○ www.usgbc.org/DisplayPage.aspx?CMSPageID=148, the list of pilot projects.

- Gas Technology Institute Sustainable Energy Planning Office, U.S. IC-SUSD Team: "Sustainable Urban System Design for the Greater San Diego-Tijuana Binational Metropolitan Region.” Official U.S. Team Submission to the International Competition for Sustainable Urban System Design, www.sdenergy.org/uploads/BinatDesignFinal022403.pdf.

- International Gas Union Special Project: Proposals for the International Competition of Sustainable Urban Systems Design. National Organizing Committee of the 22nd World Gas Conference and the Institute of Behavioral Sciences. The Institute of Behavioral Sciences, http://www.ibs.or.jp/m_pub/pub_03/book_19/book_19.html. 
- Gas Technology Institute: Blueprint for Urban Sustainability: Integrating Sustainable Energy Practices into Metropolitan Planning; With Expanded Sections on Distributed Energy Resources. Available for purchase online at: http://www.gastechnology.org/webroot/app/xn/xd.aspx?xd=10AbstractPagel040 040.xml. GRI-04/0040, February 2004.

- Magnoli, G.C.; Bonanni, L.A.; Khalaf, R.; et al. Designing a DNA for adaptive architecture: a new built environment for social sustainability. Design and Nature: Comparing Design in Nature with Science and Engineering. First International Conference. 2002, p.203-213.

- Kazimee, B.A. 2003. Sustainable urban village with vision: A comprehensive proposal for an ecologically sensitive residential community. Sustainable World 6: 813-822.

- Nichols, C. Alans. 2006. Tucson, Civano, and the sustainable energy standard. Strategic Planning for Energy and the Environment 26 (3): 34-47.

- Yamaguchi, Y.; Shimoda, Y; and Mizuno, M. 2007. Transition to a sustainable urban energy system from a long-term perspective: Case study in a Japanese business district. Energy and Buildings 39 (1): 1-12.

- Clark II, Woodrow W. 2007. Partnerships in creating agile sustainable development communities. Journal of Cleaner Production 15 (3): 294-302.

- Hoffman, S. M., and High-Pippert, A.. 2005. Community energy: A social architecture for an alternative energy future. Bulletin of Science, Technology and Society 25 (5): 387-401.

- Franko, R, et al. 2007. Developing Sustainable Planned Communities. Urban Land Institute. ISBN: 978-0-87420-991-4. Available at: www.uli.org

- Packard Foundation. 2002. Building for Sustainability. Available at: http://www.hpsarch.com/TitlePageSpecial/2002-Report.pdf

\subsection{Specific development examples}

- Geos Living 360, Arvada Colorado. Sustainable development efforts. http://www.Discovergeos.com.

- Dewees Island, S. Carolina. Environmental conscious project. http://www.oikos.com/esb/49/dewees.html.

- Illinois Institute of Technology Sustainable Village: Krauss M: Tellabs chief funds IIT environment project. Chicago Sun Times. February 14, 2005.

- Christensen, K. 1999. Directory of Eco-villages in Europe (Book ReviewReviews the book Directory of Eco-villages in Europe). Utopian Studies; 10 (1): p160. EBSCOhost, http://web.ebscohost.com/ehost/detail? vid=1\&hid=8\&sid=d5287682-05e149fd-a493-105cbac0fb23\%40SRCSM2.

- Sustainable Seattle, http://www.sustainableseattle.org. 


\section{Solar/Zero-Energy Buildings and/or Micro-Grids}

Improving on the sustainable, passive solar community includes incorporating technologies to make renewable energy living possible: solar/zero-energy homes, and/or community-based centralized renewable power generation systems (also known as micro grids).

\subsection{Information review sources on solar/zero-energy buildings}

- The U.S. Department of Energy Building America Program supports a wide range of projects to develop and encourage home building using efficient design and efficient and renewable energy technology, www.buildingamerica.gov

- Valuation of zero-energy homes by builders: NAHB Research Center, Inc. (August 2005). Zero Energy Home Project; ZEH Market Analysis.

- Hammon, R.“The Near-Zero Energy House.” Solar Today. May/June 2005.

- B. C. Farhar, B.C.; Coburn, T.C. A New Market Paradigm for Zero-Energy Homes: The Comparative San Diego Case Study. NREL/TP-550-38304-02. Golden, CO: National Renewable Energy Laboratory, December 2006. http://www.nrel.gov/docs/fy07osti/38304-01.pdf. http://www.nrel.gov/docs/fy07osti/38304-02.pdf.

- United States GBC 2000 Team: Supporting Green Buildings and Communities for a Healthy and Prosperous Planet. Green Building Challenge 2000 Brochure. (2000). NREL Report No. BR-810-29045; DOE/GO-102000-11292, http://www.nrel.gov/docs/fy01osti/29045.pdf.

- DOE: Moving Towards Zero Energy Homes: New Fact Sheet Series Available. http://www.nrel.gov/publications/

- PM Engineer: Web Case Study - California Developer Creates Zero Energy Home Development. 2004. 2.2. Specific solar/zero-energy building development examples.

\subsection{Specific solar/zero-energy building development examples}

- Pardee Homes has built hundreds of homes in Southern California and the Las Vegas, Nevada area, http://www.forester.net/de_0503 taking.html.

- GrupeGreen's Whitney Ranch development in Rocklin, California, http://www.grupe.com/communities/carsten/features.cfm.

- Clarum Homes' Vista Montana development in California, http://clarumzeroenergy.com/.

- Premier Homes in the Sacramento, California, area, http://www.solartoday.org/2005/may june05/ZEH.htm.

- GE Energy's Solar Systems in Premier Homes, http://www.gepower.com/about/press/en/2004_press/113004z.htm.

- Chula Vista, California Research Initiative, http://www.globalenergycenter.org/news/r_d_community.html. 
- Solar Village, Prospect New Town, Longmont, Colorado, http://www.solarvillagelife.com/home.html.

- Army Family Housing by Actus Lend Lease, Oahu, Hawaii, http://www.armyhawaiifamilyhousing.com/about us/ahfh.asp.

- Montopolis neighborhood, Austin, Texas, http://www.austinchronicle.com/gyrobase/Issue/story?oid=oid\%3A257313.

- Japan Area Home Builders' Network (JAHB Net-Aqura Home) Hyugazero $\mathrm{PV} /$ all electric standardized zero-energy home, http://www.insnet.org/ins headlines.rxml?cust=2\&id=1854\&url=http://www.ja panfs.org/db/database.cgi? $\mathrm{cmd}=\mathrm{dp} \&$ num $=1136 \& \mathrm{dp}=$ data e.html.

\subsection{Information review sources on micro-grids}

- Watson, Jim. 2004. Co-provision in sustainable energy systems: The case of micro-generation. Energy Policy 32 (17): 1981-1990.

- Abu-Sharkh, S.; Arnold, R.J.; Kohler, J.; et al. 2006. Can microgrids make a major contribution to UK energy supply? Renewable and Sustainable Energy Reviews 10 (2): 78-127.

- Spitzley, David V.; Keoleian, Gregory A.; Baron, Scott G. 2007. Life cycle energy and environmental analysis of a microgrid power pavilion. International Journal of Energy Research 31 (1): 1-13.

- Markvart, Tom. 2006. Microgrids. Power systems for the 21st Century? Refocus 7 (4): 44,46,48.

- Hibbert, Lee. 2005. Plugging renewables into the grid. Professional Engineering 18 (4): 24-25.

\subsection{Specific micro-grid development examples}

- Sonoma Mountain Village, Rohnert Park, California (1.1 MW community PV plant), http://sonomamountainvillage.com/home.htm.

- BioTown, Reynolds, Indiana, plans for ethanol, biodiesel, and flex-fuel vehicles. Longer-range plans include meeting the town's energy needs by using agricultural residues and municipal waste to produce both electricity and natural gas, http://www.in.gov/biotownusa/faqs.htm.

- Drake Landing Solar Community subdivision, Okotoks, Alberta, Canada (solarheated district space and water heating system to serve all 52 homes), http://www.dlsc.ca.

- Findhorn Ecovillage, Scotland (community wind turbine) Findhorn Ecovillage, http://www.ecovillagefindhorn.com/renewable/index.php. 


\section{Advanced and Energy Efficient Transportation}

Further building on elements one and two, element three includes adding a key technology element - advanced vehicles (electric, hybrid, plug-in hybrid, or alternative fueled) and/or energy efficient transportation (mass transit). The goal is to reduce energy use even further by not only powering homes from renewable energy, but powering cars from it as well.

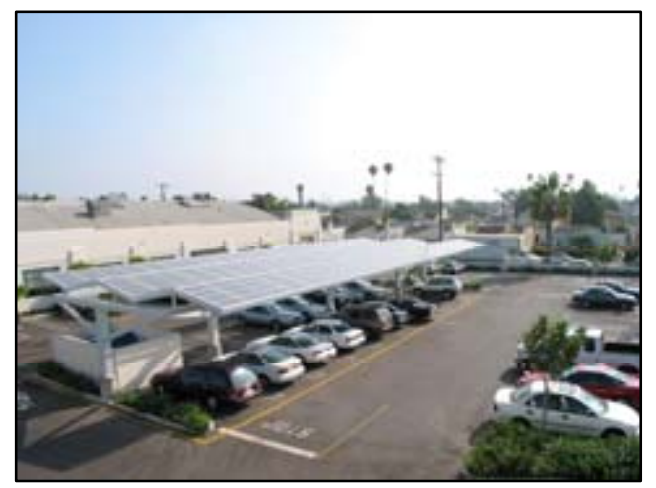

Solar car park. Courtesy of Solar Electric Vehicles

\subsection{Information review sources}

- Anonymous. Plug It In. Scientific Computing; Jan2007, Vol. 24 Issue 2, p8-8, $1 / 3 p$

- Frank, Andrew A. 2007. Plug-in Hybrid Vehicles for a Sustainable Future. American Scientist 95 (2): 158-165

- Suppes, G.J. 2006. Roles of plug-in hybrid electric vehicles in the transition to the hydrogen economy. International Journal of Hydrogen Energy 31 (3): 353360

- Kempton, Willett, and Jasna Tomic. 2005. Vehicle-to-grid power fundamentals: Calculating capacity and net revenue. Journal of Power Sources 144 (1): 268279

- Voelcker, John. 2007. Top 10 tech cars 2007. IEEE Spectrum 44 (4): 34-41

- Romm, Joseph. 2006. The car and fuel of the future. Energy Policy 34 (17): 2609-2614.

- Wills, Jonathan. 2005. Clean energy for your home - From your car. Fuel Cell Review 2 (4): 7-8.

- Science and technology-Vehicle technology-Plug and play. The Economist. 378 , no. 8462 , (2006): 78

- Environment. Giving Hybrid Cars a Real Jolt. Business Week, April 11, 2005.

\subsection{Car-sharing and mass transit examples}

- Cities like Seattle \& Washington, DC have strong transit support for car sharing. Philadelphia and Berkeley have replaced part of their city fleet via car 
sharing, and other cities are providing on-street and other parking support, http://www.carsharing.net/where.html.

- Case studies in sustainable transportation, http://www.tc.gc.ca/programs/environment/utsp/casestudiesinsustainabletranspo rtation.htm.

- Sustainable transportation success stories, http://www.smartcommunities.ncat.org/transprt/trsstoc.shtml.

\subsection{Specific plug-in/home development examples}

- Home designed with two way plug-in for electric vehicle-Toyota Dream House, Aichi Prefecture, Japan, http://tronweb.supernova.co.jp/toyotadreamhousepapi.html

- Terramor Village subdivision including charging plugs for NEVs, http://www.sustainablehomemag.com/CDA/Archives/67630008cea97010VgnV $\underline{\mathrm{CM} 100000 \mathrm{f} 932 \mathrm{a} 8 \mathrm{c} 0}$

\subsection{Advanced vehicle examples}

- Neighborhood Electric Vehicles-Global Electric Motorcars, www.gemcar.com.

- Electric scooters and motorcycles example, http://www.evc$\underline{\text { llc.com/Products.html }}$

- CalCars-PHEV conversions and info, http://www.calcars.org/.

- Energy CS-PHEV conversions, http://www.destinyusa.com/.

- Hymotion-PHEV conversions, http://www.hymotion.com/.

- Hybrids Plus-PHEV conversions, http://www.hymotion.com/.

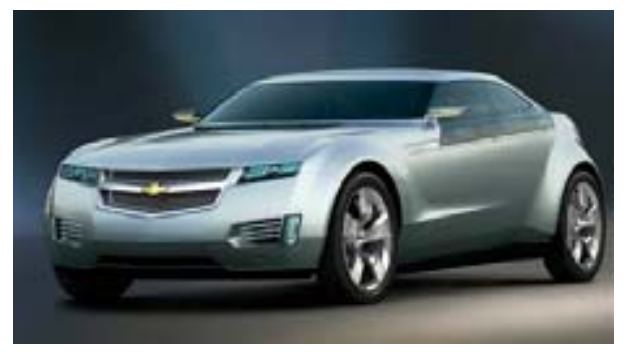

The 2007 Chevrolet Volt PHEV concept car

\section{Utility Role Expansion-Power Generation \& Power Management}

Taking another step towards becoming a Renewable Energy Community includes the local utility company and maximizing renewable energy economies of scale. Essentially this means that the nation's increasing reliance on renewable energy will result in more distributed renewable power on the utility grid and micro-community power grids, allowing for communities to take advantage of the renewable energy economies of scale. 


\subsection{Information review sources}

- Guterl, F.; Romano, A.2004. Examples from around the world of feeding energy back to grid: "People Power." Newsweek. September 13.

- Coll-Mayor, D.; Picos, R.; Garcia-Moreno, E. State of the art of the virtual utility: the smart distributed generation network. International Journal of Energy Research. 28 (1).

- Hain, J.J.; Ault, G.W.; Galloway, S.J.; Cruden, A.; McDonald, J.R. 2005. Additional renewable energy growth through small-scale community orientated energy policies. Energy Policy 33 (9): 1199.

- Hain, J.J.; Ault, G.W.; Galloway, S.J.; Gair, S.; McDonald, J.R. 2003. Towards a community impact assessment of renewable energy systems: a case study in the Isle of Islay. Proceedings of UPEC 2003, Cyprus.

\subsection{Specific examples of progressive utilities}

- Austin, TX, http://www.austinenergy.com/.

- Sacramento, CA, http://www.smud.org/

- Minnesota, http://www.puc.state.mn.us/.

- Wisconsin, http://psc.wi.gov/.

\subsection{Specific examples of utilities engaging in renewable community development}

- Austin City is studying the possibility making all new single-family homes "Zero-Energy Capable Homes" with rebates for PHEVs by the year 2015, http://www.ci.austin.tx.us/news/2006/ae zero energy homes.htm.

- The Japan Area Home Builders Network in Japan has built a model standardized home that totally eliminates utility cost by being able to sell electricity back to the grid equivalent to the cost of grid electricity that it does use:

http://www.insnet.org/ins headlines.rxml?cust=2\&id=1854\&url=http://www.japanfs.or $\mathrm{g} / \mathrm{db} /$ database.cgi? $\mathrm{cmd}=\mathrm{dp} \&$ num $=1136 \& \mathrm{dp}=$ data $\_. h t m l$,

\section{Putting it All Together for a Renewable Energy Community}

Developing a Renewable Energy Community requires that we plan developments using a systems approach to integrate all four of the elements previously discussed in the main paper. It also requires that we scale up what we already know how to do-place an increasing emphasis on energy efficiency, embrace energy conservation, and use significantly more renewable energy. This is an opportunity to demonstrate that we can have vibrant communities that use significantly less conventional energy. It will require that we "reinvent" how to meet our nations need for housing and transportation by viewing energy systems for homes and vehicles as one integrated system connected to a utility andlor a distributed power generation network. 


\subsection{Information review sources}

- Penney, T., and J. Elling. 2006. Plugging In to Renewable Communities How transportation based on renewable energy-powered communities may solve our addiction to fossil resources. Solar Today 20 (3): 22-25. http://www.solartoday.org/2006/may june06/plugging in.htm.

- Penney, T., and J. Elling. 2006. The Race to Connect Cars, Communities and Renewables. GeoTimes. August 2005. http://www.geotimes.org/aug05/feature pluginhybrid.html.

- Droege, P. 2007. Renewable City. Published by John Wiley \& Sons. http://www.renewablecity.org/

\subsection{Specific development examples}

To our knowledge, a Renewable Energy Community, as defined by NREL, has not been created. Yet many developments go a long way towards the goal and there are ambitious plans in the works.

- Beddington Zero Energy Development (BedZED), England. BedZED is planned to be carbon neutral and designed to enhance the environmental dimensions, with strong emphasis on roof gardens, sunlight, solar energy, reduction of energy consumption and waste water recycling. BedZED provides about 100 mixed-use homes, and a green transport plan promotes walking, cycling, and use of public transport, including a car pool for residents.

- http://www.bioregional.com/programme projects/ecohous prog/bedzed/b dzed hpg.htm

O http://www.arup.com/_assets/_download/download68.pdf

- Dongtan, Shanghai, China. This sustainable city of 80,000 people will include a $33-\mathrm{mW}$ electrical generating plant using rice-husk agricultural residue as a feedstock, together with a district heating system using the waste heat from the plant to meet all of the city's water, space heating, and cooling needs. It is a former agricultural 1,600-acre river island. High density, along with adjacent location of the power plant, will make the district heating system possible and also reduce need for car access and energy use for transportation. http://www.arup.com/eastasia/project.cfm?pageid=7047.

- Samsoe Renewable Energy Island, Denmark. This island provides $70 \%$ of its heat with four district heating plants on the island, plus several private heating systems burning plant oil. Gradually, islanders are increasingly using biodiesel for liquid fuels. For electricity, islanders installed 15 new wind turbines. The turbines on land are owned individually by local farmers. To compensate for liquid fuels used in transportation, the islanders installed ten 2.3 MW wind turbines offshore; two of which are cooperatively owned by 450 shareholders. There are about 4,500 residents on the island. http://ec.europa.eu/energy/idae site/deploy/prj029/prj029_1.html. 
- Destiny USA, Syracuse, New York. On a 250-acre redevelopment site in Syracuse, Destiny USA is planned as a 75-million-square-foot, 25,000/60,000room hotel/commercial/retail/transportation/entertainment "retail city" convention center complex. The mall is to be powered by renewable sources including solar and biodiesel electric generation onsite, wind (both built and purchased) offsite, natural gas fuel cells, PV, and GEM neighborhood electric vehicles. Developers plan to complete the complex in about five years. http://www.destinyusa.com/.

- Sarasota, Florida. Sarasota County announced on June 10, 2006, the creation of the nation's first national renewable community in recognition of the county's commitment to developing an energy efficient community that will be sustainable far into the future. To help achieve this future community, a partnership was formed between Sarasota County government officials, home builders, Florida Power \& Light Co., and the National Renewable Energy Laboratory. http://scgov.net/PublicCommunications/MediaRelations/documents/68NRrenewablecommunity_1FINAL.pdf. 


\section{REPORT DOCUMENTATION PAGE}

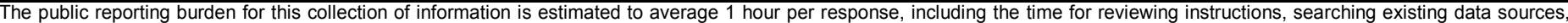

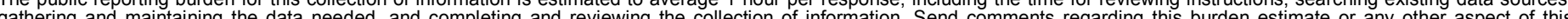

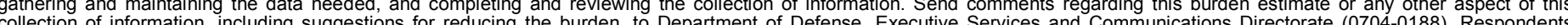

should be aware that notwithstanding any other provision of law, no person shall be subject to any pena

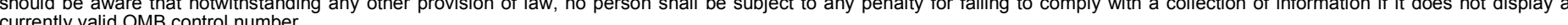

PLEASE DO NOT RETURN YOUR FORM TO THE ABOVE ORGANIZATION.

\begin{tabular}{l|l|l|l} 
1. REPORT DATE $(D D-M M-Y Y Y Y)$ & 2. REPORT TYPE & 3. DATES COVERED (FrOm - TO)
\end{tabular}

January 2008

Technical report

4. TITLE AND SUBTITLE

A Renewable Energy Community: Key Elements

5a. CONTRACT NUMBER

DE-AC36-99-G010337

5b. GRANT NUMBER

5c. PROGRAM ELEMENT NUMBER

6. AUTHOR(S)

N. Carlisle, J. Elling, and T. Penney

5d. PROJECT NUMBER

NREL/TP-540-42774

5e. TASK NUMBER

2940.0007

5f. WORK UNIT NUMBER

7. PERFORMING ORGANIZATION NAME(S) AND ADDRESS(ES)

National Renewable Energy Laboratory

1617 Cole Blvd.

Golden, CO 80401-3393

9. SPONSORING/MONITORING AGENCY NAME(S) AND ADDRESS(ES)

10. SPONSOR/MONITOR'S ACRONYM(S)

NREL

11. SPONSORING/MONITORING AGENCY REPORT NUMBER

12. DISTRIBUTION AVAILABILITY STATEMENT

National Technical Information Service

U.S. Department of Commerce

5285 Port Royal Road

Springfield, VA 22161

13. SUPPLEMENTARY NOTES

14. ABSTRACT (Maximum 200 Words)

Designing new communities using a renewable energy systems approach-with sustainable planning, zero-energy

homes, advanced vehicles, and innovative utility interconnections-can reduce energy use.

15. SUBJECT TERMS

Renewable Energy Communities, systems approach, sustainable planning, zero-energy homes, advanced vehicles, utility interconnections

\begin{tabular}{|c|c|c|c|c|}
\hline 16. SECURITY & CLASSIFICATI & N OF: & 17. LIMITATION & 18. NUMBER \\
\hline $\begin{array}{l}\text { a. REPORT } \\
\text { Unclassified }\end{array}$ & $\begin{array}{l}\text { b. ABSTRACT } \\
\text { Unclassified }\end{array}$ & $\begin{array}{l}\text { c. THIS PAGE } \\
\text { Unclassified }\end{array}$ & $\begin{array}{l}\text { OF ABSTRACT } \\
\text { UL }\end{array}$ & \\
\hline
\end{tabular}

19a. NAME OF RESPONSIBLE PERSON

19b. TELEPHONE NUMBER (Include area code) 